\title{
Syntheses of the Caddo Archaeological Record
}

Timothy K. Perttula

Heritage Research Center, Stephen F. Austin State University

Follow this and additional works at: https://scholarworks.sfasu.edu/ita

Part of the American Material Culture Commons, Archaeological Anthropology Commons, Environmental Studies Commons, Other American Studies Commons, Other Arts and Humanities Commons, Other History of Art, Architecture, and Archaeology Commons, and the United States History Commons

Tell us how this article helped you.

This Article is brought to you for free and open access by the Center for Regional Heritage Research at SFA ScholarWorks. It has been accepted for inclusion in Index of Texas Archaeology: Open Access Gray Literature from the Lone Star State by an authorized editor of SFA ScholarWorks. For more information, please contact cdsscholarworks@sfasu.edu. 


\section{Syntheses of the Caddo Archaeological Record}

Creative Commons License

(c) (i) (8)

This work is licensed under a Creative Commons Attribution-NonCommercial 4.0 International License 


\section{Syntheses of The Caddo ARChaEOlogical Record}

\section{Timothy K. Perttula}

The pursuit of Caddo archaeological research over the last 100+ years has led to considerable gains during that time in the understanding of such research issues as settlement patterning, subsistence change and diet, health and adaptive efficiency, sociopolitical organization, ceremony and ritual, iconography, and exchange networks among the Caddo peoples and their past communities (see Girard et al. 2014). Much of this has been the result of intensive cultural resource management investigations in southwestern Arkansas, northwestern Louisiana, eastern Oklahoma, and East Texas, along with focused archaeological research projects conducted by university archaeological programs and state and regional archaeological societies. The years ahead promise to continue to shed new light on the character and understanding of the ca. A.D. 8501850s Caddo archaeological record.

Despite these hard-won gains in our understanding and explanation of the Caddo archaeological record, Caddo archaeological research investigations remain almost exclusively parochial and state-bound (i.e., based on the detailed analyses of particular sites or groups of sites in a regional locality). Large scale syntheses (i.e., macro-regional in scope and crossing state lines) and grand challenges (e.g., Kintigh et al. 2014) of the Caddo archaeological data are needed if we are to ever fully appreciate, detail, and refine the character of the native histories of Caddo peoples. As in the Southwestern United States and the study of ancestral Pueblo communities through successful large scale and multi-year synthetic research and accompanying creation of databases-as in the Chaco Research Archive, the Southwest Social Networks databases, and the Village Ecodynamics Project—the "ability of scholars to pursue synthetic research depends on the commitment of the... archaeological community to make project data available in state archaeological record files, museums, and burgeoning digital repositories" (Schachner 2015:56, 84).

While considerable steps have been made by the Caddo archaeological community in creating databases of archaeological data, more efforts along these lines are still needed. There are large and specialized digital Caddo databases being cumulatively developed concerning such things as radiocarbon dating of features and archaeological deposits, vessel documentation and digitization, ceramic sherd databases, databases of the instrumental neutron activation analysis and petrographic analysis of Caddo ceramic vessels and sherds, as well as the distribution of novaculite artifacts-and there are surely othersbut these efforts need to be expanded to reach across state lines and individual researchers to extend their full use and capabilities for Caddo archaeologists. Just as importantly, we also need the collaboration of scholars working in all parts of the Caddo archaeological area on large-scale and major research questions, so as to be able to actively engage in the comparison of the variable regional character of the Caddo archaeological record in material culture expressions, social and political practices, use of landscapes, subsistence strategies and use of cultivated plants, interaction with neighbors, and the tempo of cultural changes. The synthesis of the stylistically diverse Caddo ceramic wares across the Caddo area would seem to be tailor-made for studies of ancestral Caddo social networks and social identities that rely on large regional ceramic datasets (see Collar et al. 2015; Mills et al. 2015), but such social network syntheses wait to be done.

If large-scale syntheses of the Caddo archaeological record are important to undertake, how can the collaboration of Caddo archaeologists be encouraged? How can databases of specific sets of information be created, designed, and shared between Caddo archaeologists working on common research problems? I think the Caddo Conference Organization (CCO), the CCO's website (www.caddoconference.org), and the annual Caddo Conference have very important roles to play in fostering a research climate where "big" syntheses can be developed through both short-term and long-term project collaborations and database (spatial and 
analytical) compilations. As a non-profit organization, the CCO can and should develop research projects of varying scopes that would rely on the collaboration of CCO members working in different regions on research questions and problems of mutual interest and making such information and datasets accessible on their website or other platforms; the CCO should represent the broader shared interests of its members, most of whom are archaeologists. The Caddo Conference could and should be a venue where such research goals, questions, problems, and projects of interest can be identified and developed, perhaps in discussion and roundtable forums, or in more informal discussions. To my mind, the Caddo Conference should be much more than simply 20 minute presentations and Caddo dances. What I would suggest is now needed is a much stronger thematic or topical component to the Conference, one where related archaeological papers can be organized that focus on themes or topics of broad and mutual interest (i.e., ancestral Caddo social networks), and also focus on the publication of the papers, perhaps in the Caddo Archeology Journal or other publication venues.

Who knows what the future of Caddo archaeology will hold, or what kinds of new and improved understandings of the Caddo archaeological record will come in the years ahead. Without expending effort in large-scale syntheses of ancestral Caddo archaeology, we will not be taking full advantage of the richness of our knowledge of Caddo native history.

\section{Acknowledgments}

I appreciate the comments received by Ross C. Fields, Jeff Girard, Robert Z. Selden, Jr., and Mary Beth Trubitt on this MS.

\section{References Cited}

Collar, Anna, Fiona Coward, Tom Brughmans, and Barbara J. Mills

2015 Networks in Archaeololgy: Phenomena, Abstraction, Representation. Journal of Archaeological Method and Theory 22:1-32.

Girard, Jeffrey S., Timothy K. Perttula, and Mary Beth Trubitt

2014 Caddo Connections: Cultural Interactions Within and Beyond the Caddo World. Rowan \& Littlefield, Lanham, Maryland.

Kintigh, Kenneth W., Jeffrey H. Altschul, Mary C. Beaudry, Robert D. Drennan, Ann P. Kinzig, Timothy A. Kohler, W. Frederick Limp, Herbert D. G. Maschner, William K. Michener, Timothy R. Pauketat, Peter Peregrine, Jeremy A. Sabloff, Tony J. Wilkinson, Henry T. Wright, and Melina A. Zeder

2014 Grand Challenges for Archaeology. American Antiquity 79(1):5-24.

Mills, Barbara J., Matthew A. Peeples, W. Randall Haas, Jr., Lewis Borck, Jeffrey J. Clark, and John M. Roberts, jr. 2015 Multiscalar Perspectives on Social Networks in the Late Prehispanic Southwest. American Antiquity 80(1):3-24.

Schachner, Gregson

2015 Ancestral Pueblo Archaeology: The Value of Synthesis. Journal of Archaeological Research 23(1):49113. 